\title{
20. 生産システム
}

$20 \cdot 1$ 総

貺

生産システムの高度化が，機械化から自動化・無人 化へと移行するにつれて，部品供給，加工・組立作業 等のハードウェアの側面を重視する考え方から，シス テムのより効率的な設計・運党をめざすためには，経 済性・生産計画・スケジューリング・保全・教育等の ソフトウェアの側面をより重視する方向に変わりつつ ある。これはばく大な設䚚投資の回収問題を含めて, 工場経営管理の立場からよりシビアに生産システムを 見直す時期にきているといってもよい(1)(4).FMS, FA 導入のための啓もうの時期はおわり，これからは技 術・経営の両側面でこれまでにない困難な問題に直面 することが予想される(5)(6).

コスト面から企画・設計部門にまでさかのぽっての FAの見直し・検討(7)やFAの経済性 ${ }^{(8)}$, 機械工業にお ける保全戦略 ${ }^{(9)} や$ 保全活動の具体的事例 ${ }^{(9)-(12)}$, システ ム設計・運用のシミュレーションによる稼働率の事前

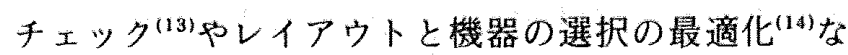
どの記事は,ソフト面の問題を検討する参考となろう。

生産システムにかかわる人の問題としては, 仕事の 質の変化によって雇用・再教育・配置の重要性が顥在 化してきている(15)(16). メカトロニクスに代表される技 術革新に対応するための技術者養成は，企業の体貿改 善活動とともに、全業種にわたり中小企業をも含めて 皘極的に取り組まなければならない課題であ $\zeta^{(17) \sim(19)}$.

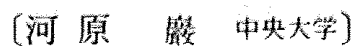

\section{$20 \cdot 2$ 工程・作業システム}

FMSの概念が単なるマシニングセンタへの部品・ 材料の供給, 加工工程, 完成品搬出までの範用から, 工場の全製造工程に適用されるに従って，組立工程の 自動化への対応が問題となってきた，組立工程の自動 化に関する固有技術の問題は別にして, (1) 自動化設 備費用と製品ライフおよび非自動化の場合のコスト比 較, (2) 自動化に伴うラインパランスやスケジューリ ングの変化, (3) 作業者の作業内容の変化や再配筧打 よび教育の問題, (4) 自動化設備の稼働率や保守・保全 の問題，(5) 他職場や生産システムの整合性などが運

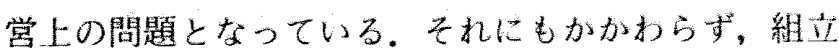
工程にロポットを導入，自動化し品質向上，生産量の 增大など生産性をあげた企業が見られるのは㴤目に值
する(20) 〜22).ここで共通していることは製品が家㲠や 計算機の周辺機器などで, 比較的組立部品が小形軽量 である程度の量産品であることである。来た口ボッ トの作業は非常に単純で要装作業も少なく、短いサイ クルタイムで多工程としているのが特徴である。これ は製品の機種変更の際の工程の立上がりや保守・保全 対策を容易にするための配㭸と思われる。

自動組立を行うためには，それに適した設部法が要 求され，その適応性の評価はますます重要なものとな ってきた。その一例として垂直積上げ式で自動組立を 行う場合の評価要素は (1) 組付方向の垂植化, (2) 機 能ブロックのモジュール化, 単純化, 嫩淮化, (3) 締結 の単純化, (4) 機棈の単純化, (5) 機能構造の兼用化, (6) 製品系列の単純化, (7) 部品自動供給の容易化, な どがあげられている ${ }^{(23)}$.このような製造工程優先の考 え方はここれまで企業内に扔いて設計部門に比較して, 発言力の弱かった製造部門の地位が向上したことを意 味し、トータル的な考光方が漫透してきたものと考え られる.

FMSの概念をさらに進めたものとして，FMC (Flexible Manufacturing System Complex) の寒験 プラントが完成しつつあることも注目すべきことであ る.これは多品種中少量生産を対象とした諳算機制御 によるNC工作機械群と自動搬送装监からなる総合 生産システムで複合生痤シスデムと呼ばれるる21(25),

自動機械が生産工程に筫入され，無人て加工や組吉 が行われるようになると、自動機械に適した合理的な 動きは，どのような軌跡となるか，どの要絜作業を優 先して作業順序を決めるか，宗た自動機械の能力評価 をどうするかなども考えなければならない。これらに

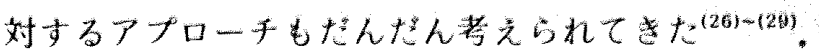

しかしながら，自動機械が導入されても，完全無人 化ではなく,人間一機械システムが現段階では一般的で ある。ここでの人間の役割は，固有技術あるいはコス 卜面で自動化できない作業や材料の供䋹㧍よび搬出の

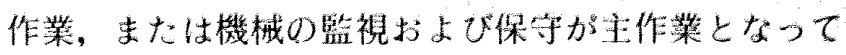
きている。つまり装留工業の形態へ移行しつつある。 人間一機械システムで人間の能力を優先したシステム を設計するか，それとも機械の能力を優先するか，そ の辺の調和をどうするかは，これからの生産システム を考える際の基本的かつ重要な課題である。これらに 関して、機械化の範姍，自動化と人間性，自動化の中 での安全性や人間工学的考察结主要なテーマとな 
$3^{(36)+334}$.

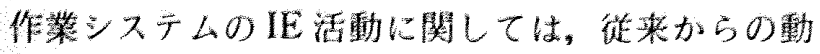

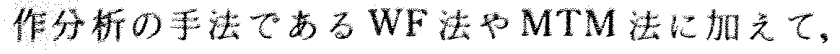
MODAPTS (Modular Arrangement of

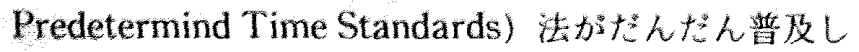

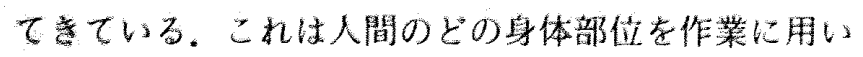
るか心上って、概略の時間俅得る手法で動作の移動

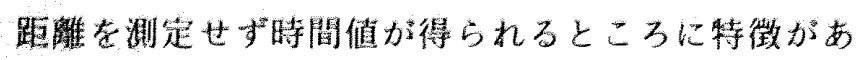

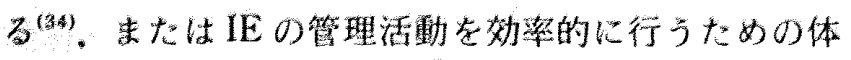

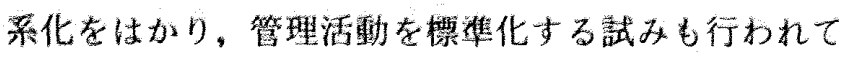

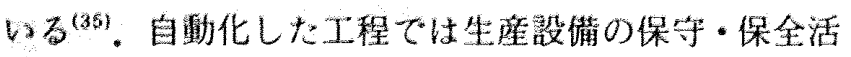

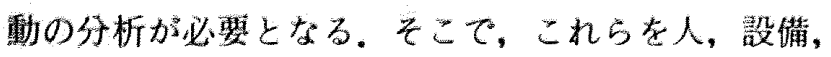
方法に分け解析与る手法や自野化工程を因子分析の手

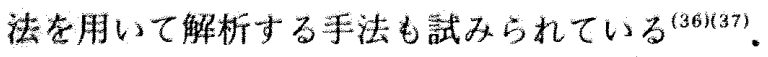

レイアウト技法に関しては。グラフの理論を用いて， $n$ 台の設備を人やものが移動する距離を鼠小にする方

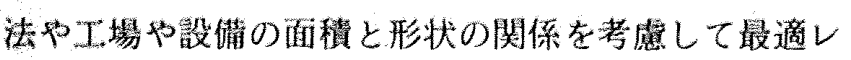
イアウトを考える手法がみられる(38)(39).

ショプ・ショッナにおける段取作菜当 FMC (Flexible Manufacturing Cell) の奕入によりたんた 儿目動化されつつある.ジョフ・ショップでは加工ロ ット少イズ決める要因として, 段取時間が重要な意 味を娄っているが、この段取作業の自動化はロットサ

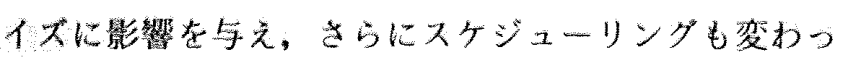
てくるものと想われる。类たロットサイスと作菜時間, 交撸工具数と作業時閻の関倸をコスト面で比較し, 白

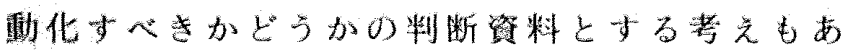
$z^{(40)}$.

トータルな生瘦管理システムとしては，MRPを基

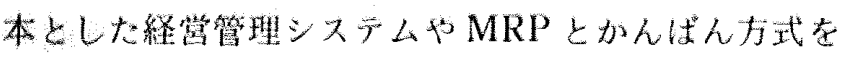

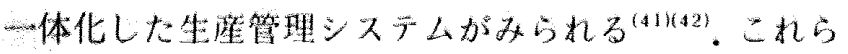

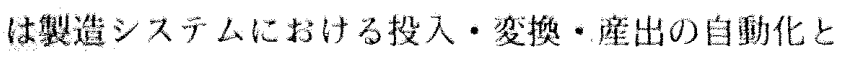

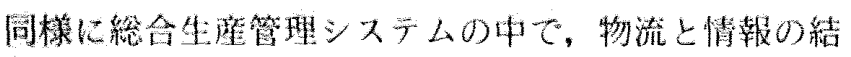

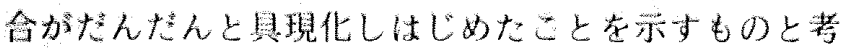
2sta.

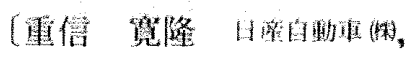

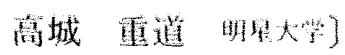

\section{$20 \cdot 3$ 計画・管理システム}

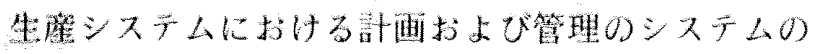
町究化，FMS

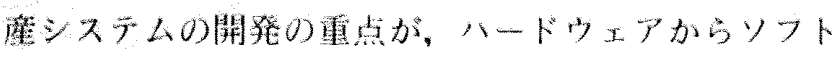

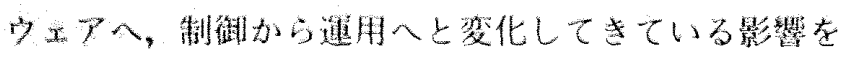

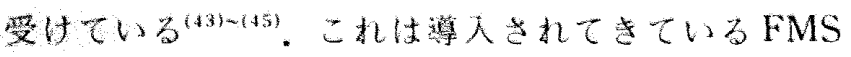

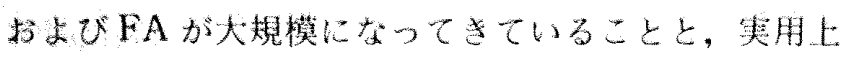

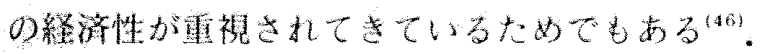

このことから,生麾計画かよび管理に関する研究も,

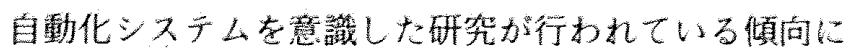

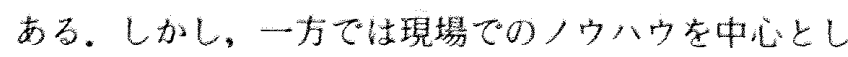
なシステム作りは梦千低晹であった。

生産全体口来軟性老取报った60)で，GT(Group

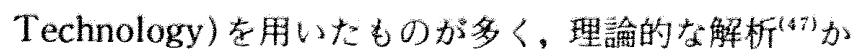

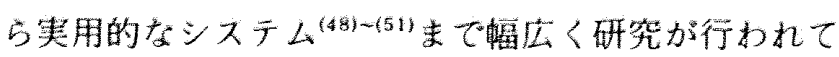
《.

スケジューリングに咸しては、対象とするモデルの

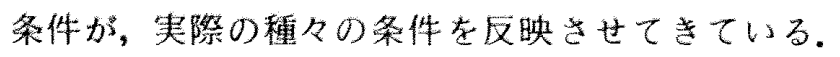
FMS 考隐した般送およびバッファを持つジョブ・ ショップスタジューリング゚(52), MRP下のロットスケ ジューリング(53)，多品種加エラインのスケジューリン

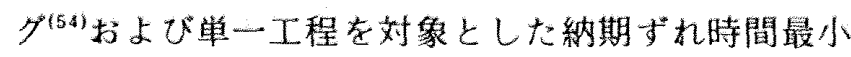
のスケジューリング(55)などがそれである。

工程設尌については，GTによる変成形（Variant Type) は研究から䒠用化の段階入移行しつつあり ${ }^{(56)}$, それに変わって創成形 (Generative Type) が研究と して発表されてきている。旋削を对象としたも $\sigma^{(56) \sim(58)}$ ，角物を対象としたもの ${ }^{(59)(60)}$ などがある、い ずれも，CADの形状七广ラを用いて対象部品の形状 を知述して，工具形状により除去部を表現している。 このほかに，機械加工の工程設計に，情報䑖の概念を 用いたもの がが新たに提案されている。

設備計面の評価では, 経娍性に対李関心が高く,

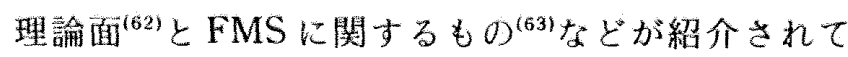
W子.

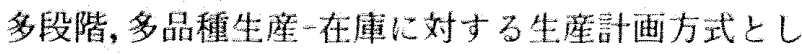
てのMRPが日本にお゙いて棒用化の段階に入り，いく

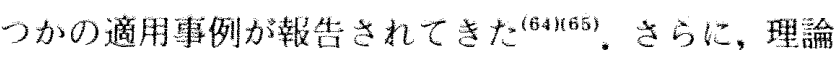

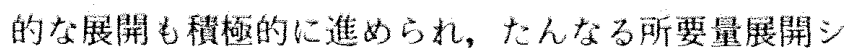
ステムではなく，財雅管理，経営計画との接合を图力 t BRP (Business Requirements Planning) ${ }^{(66)}, \pm 5$ に物流領域に过飞適用拉大を図ったDRP (Distribution Requirements Planning) 入の展開が見

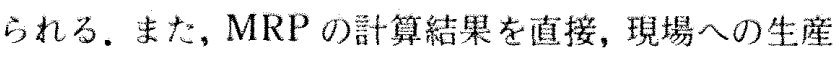
指示に結びのるための研焭当進められてい $3^{(67)(68)}$.

リアルタイムに人，設借を制御，管理する生産進行

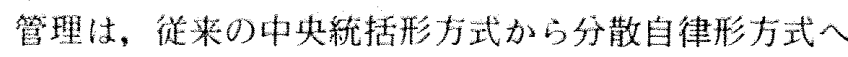
移行している。後工程の仕挂量の增減に上り自工程の 白律調整を図るかんばん万式がての代表例であるが, 促来, 少品種フローシ ヨップに限定されていた。近年, マイクロコンピュータ, ネットワーク技街の岸人によ り，多品程生産やジョブ・ショップて分散目律形管 理方式の適用が推進されて娄ている 